\title{
CHROMOSOME NUMBERS FOR Anthurium AND Philodendron spp. (ARACEAE) OCCURRING IN BAHIA, BRAZIL
}

\author{
Ana Lúcia Pires Cotias-de-Oliveira ${ }^{1}$, Maria Lenise Silva Guedes ${ }^{2}$ and Ervene Cerqueira Barreto ${ }^{1}$
}

\begin{abstract}
Chromosome numbers for four species of Anthurium and four species of Philodendron from Bahia, Brazil, were determined. New counts $2 \mathrm{n}=30$ for $A$. longipes and $A$. affine, $2 \mathrm{n}=32$ for $P$. pedatum and $2 \mathrm{n}=34 P$. blanchetianum and $P$. pachyphyllum represent the first reports for these species. The $2 n=32$ found for $P$. imbe and $2 n=90$ for $A$. bellum differ from earlier reports, whereas $2 \mathrm{n}=30$ and 60 for $A$. pentaphyllum var. pentaphyllum confirms previous counts. $A$. affine had one to four $\mathrm{B}$-chromosomes. We suggest secondary base numbers $x=15$ for Anthurium and $x=16,17$ and 18 for Philodendron, produced by hybridizations and duplications involving the primary base numbers $x=7,8$ and 9 .
\end{abstract}

\section{INTRODUCTION}

Araceae comprises about 105 genera and more than 3,300 species, predominantly distributed in the tropical areas of Asia and South America. Anthurium and Philodendron are exclusively Neotropical, with about 800 and 350-400 species known, respectively, together accounting for almost half of the species in this family. Anthurium is also the most complex genus, from a taxonomic viewpoint, due to its large morphological diversity and great phenotypic plasticity. It is adapted to a number of different tropical wet forest environments, as well as caatinga, cerrado, and restingas (coastal forest with sandy soil).

There is a need to generate cytological and morphological information useful for examining relationships within and between sections in these large genera (Croat and Sheffer, 1983). The majority of Anthurium species have $2 n=30$ chromosomes. Some are polyploid with $2 n=60$, while a few species have $2 n=20$ to 124 chromosomes (Petersen, 1989). Chromosome analyses are available for only $20 \%$ of the species in this genus.

Inflorescence, floral morphology and anatomy are sufficiently variable in Philodendron, especially subgenus Philodendron, to furnish a useful basis for extending and improving the infrageneric classification. However, Mayo (1990) also indicates that the study of other characters is highly desirable. Chromosome counts in the genus are available for only $10 \%$ of the species, with a predominance of $2 n=32,34$ and 36 , and isolated counts of $2 n=30$ and 33. A check-list of species from the State of Bahia, includes 29 Anthurium species and 27 Philodendron spe-

${ }^{1}$ Departamento de Biologia Geral, Instituto de Biologia, Universidade Federal da Bahia, Campus Universitário de Ondina, 40170-290 Salvador, BA, Brasil. Send correspondence to A.L.P.C.O.

${ }^{2}$ Departamento de Botânica, Instituto de Biologia, Universidade Federal da Bahia, Campus Universitário de Ondina, 40170-290 Salvador, BA, Brasil. cies (Mayo, S.J., unpublished results). In this report, we assess the chromosome numbers of four Anthurium species and four Philodendron species, among those listed by Mayo.

\section{MATERIAL AND METHODS}

Samples were collected from natural habitats, except $P$. pedatum which was cultivated as an ornamental. Voucher specimens were prepared and deposited in the herbarium ALCB of the Instituto de Biologia, Universidade Federal da Bahia, Salvador, Brazil (Table I).

Root-tips for cytological preparations were collected from potted plants and pretreated in an aqueous solution of 8-hydroxyquinoline for $4 \mathrm{~h}$ at $18^{\circ} \mathrm{C}$ and fixed in 1:3 acetic alcohol for 18-24 h. Root-tips were transferred to $70 \%$ alcohol and stored at $4^{\circ} \mathrm{C}$. They were then hydrolyzed in $1 \mathrm{~N} \mathrm{HCl}$ for $8 \mathrm{~min}$ at $60^{\circ} \mathrm{C}$ and stained following the Feulgen method (Sharma and Sharma, 1980). Squashes were made in a $1 \%$ aceto-carmine solution. Coverslips were removed in $45 \%$ acetic acid and the slides and the coverslips mounted in Canada balsam. At least 10 metaphases of each species were examined for chromosome counts.

\section{RESULTS AND DISCUSSION}

The Anthurium species had somatic chromosome numbers of $2 n=30,60$ and 90, whereas the Philodendron species had $2 \mathrm{n}=32$ and 34 (Table I, Figures 1-3). The $A$. affine karyotype consists of eight pairs with a centromere in a median position, and seven in the submedian position, one pair of which has satellites on the distal short arm. The number of B-chromosomes in the karyotypes derived from cells of the same and different plants varied from one to four (Figure 1). The B-chromosomes of this species are large and can be distinguished from satellites. The latter are easily lost in the squash. This is a typical member of section Pachyneurium. A majority of such species are $2 \mathrm{n}=30$, with some $2 \mathrm{n}=60$, and an isolated count 
Table I - Voucher number, origin and chromosome number of Anthurium and Philodendron species.

\begin{tabular}{|c|c|c|c|c|c|c|c|}
\hline \multirow[t]{2}{*}{ Species } & \multirow{2}{*}{$\begin{array}{l}\text { Voucher } \\
\text { number }\end{array}$} & \multirow{2}{*}{$\begin{array}{c}\text { Plants } \\
\text { analyzed }\end{array}$} & \multirow{2}{*}{$\begin{array}{l}\text { Collection } \\
\text { locality }\end{array}$} & \multirow{2}{*}{$\begin{array}{l}\text { Present count } \\
2 \mathrm{n}\end{array}$} & \multicolumn{3}{|r|}{ Previous count } \\
\hline & & & & & $\mathrm{n}$ & $2 n$ & Authors \\
\hline A. affine Schott & ALCB-026689 & $>10$ & Salvador & $30+1-4 B$ & - & - & - \\
\hline A. longipes N.E. Brown & ALCB-027780 & $>10$ & Salvador & 30 & - & - & - \\
\hline A. bellum Schott & ALCB-027779 & $>10$ & Cachoeira & 90 & $\begin{array}{l}- \\
28\end{array}$ & $\begin{array}{l}30 \\
56\end{array}$ & $\begin{array}{l}\text { Sheffer and Croat, } 1983 \\
\text { Mookerjea, } 1955 \\
\text { Bhattacharya, } 1976 \\
\text { (apud Petersen, 1989) }\end{array}$ \\
\hline $\begin{array}{l}\text { A. pentaphyllum(Aubl.) G. Don } \\
\text { var. pentaphyllum }\end{array}$ & ALCB-027978 & 3 & Cachoeira & 30 & - & 30 & Pfitzer, 1957 \\
\hline & ALCB-027473 & 1 & Simões Filho & 60 & - & 60 & $\begin{array}{l}\text { Sheffer and Croat, } 1983 \\
\text { Sheffer and Kamemoto, } 1976\end{array}$ \\
\hline P. blanchetianum Schott & ALCB-026037 & $>10$ & Cachoeira & 34 & - & - & - \\
\hline P. pachyphyllum Krause & ALCB-031768 & 3 & Palmeiras & 34 & - & - & - \\
\hline P. imbe Schott & ALCB-029632 & $>10$ & Salvador & 32 & 17 & $\overline{34}$ & $\begin{array}{l}\text { Pfitzer, } 1957 \\
\text { Tsuchiya and Takada, } 1962\end{array}$ \\
\hline P. pedatum (Hook.) Kunth & ALCB-029634 & 1 & Salvador & 32 & - & - & - \\
\hline
\end{tabular}

of $2 \mathrm{n}=48$ in A. jenmanii (Sheffer and Kamemoto, 1976; Sheffer and Croat, 1983).

The number of somatic chromosomes in A. longipes is $2 \mathrm{n}=30$. Chromosomes with the centromere in the submedian position predominated. A. bellum and A. longipes belong to section Urospadix, which is apparently based on $2 \mathrm{n}=30$ (Croat and Sheffer, 1983). Thus, A. bellum, 2n $=90$, may represent a hexaploid. This count disagrees with previous determinations of $2 \mathrm{n}=56$ (Mookerjea, 1955) and $\mathrm{n}=28$ (Bhattacharya, 1976 apud Petersen, 1989). Chromosomes of A. bellum were apparently smaller compared to the rest of the species analyzed. This decrease in chromosome size may be related to a high ploidy level, which has also been observed in other genera such as Allium, Piper and Ranunculus (Brat, 1965; Samuel et al., 1986; D'Ovidio and Marchi, 1990). At least two chromosome pairs with satellites were observed. The karyotype analyzed by Mookerjea (1955) had 10 pairs with a secondary constriction, one of which had a large satellite.

The counts $2 \mathrm{n}=30$ and $2 \mathrm{n}=60$ for $A$. pentaphyllum var. pentaphyllum confirm earlier counts for this species (Gaiser, 1927 apud Petersen 1989; Sheffer and Kamemoto, 1976; Sheffer and Croat, 1983). The diploid form had one chromosome pair with satellites, while the tetraploid had two pairs of chromosomes with satellites (Figures 1,2). Analyses made by Sharma and Bhattacharya (1966) in $A$. pentaphyllum var. pentaphyllum (given as A. variable) with $2 n=60$ showed two chromosome pairs with satellites, with four fragments, while Marchant (1973) registered 2n $=60$ and one B chromosome. The latter was not observed in the present study. Similarly, Sheffer and Kamemoto (1976) determined $2 \mathrm{n}=30$ and 60 in A. pentaphyllum var. bombacifolium (given as A. aemulum) and A. pentaphyllum var. digitatum (given as A. digitatum). A. pentaphyllum is a very polymorphic species belonging to the section Dactylophyllium.
Chromosome numbers for $P$. blanchetianum and P. pachyphyllum, both $2 \mathrm{n}=34$, and $P$. pedatum, $2 \mathrm{n}=32$, were determined for the first time in this work (Figure 3). The count for $P$. imbe, $2 \mathrm{n}=32$, disagrees with previous determinations of $2 n=34$ (Tsuchiya and Takada, 1962) and $n=17$ (Pfitzer, 1957). One chromosome pair with satellites was observed in both $P$. imbe and $P$. pachyphyllum.

The majority of Philodendron species that have been studied have $2 n=34$ chromosomes; few are $2 n=32$, and an even smaller number concentrated in the subgenus Meconostigma are $2 \mathrm{n}=36$. We found no relationship between the chromosome number of a species and the subgenus or section to which it belonged. All species examined here belong to subgenus Philodendron, but $P$. blanchetianum $(2 \mathrm{n}=34)$ belongs to section Philodendron, $P$. pedatum $(2 \mathrm{n}=32)$ to section Schizophyllum, while $P$. imbe $(2 \mathrm{n}=32)$ and $P$. pachyphyllum $(2 \mathrm{n}=34)$ belong to section Calostigma. Still, the most divergent number in the genus Philodendron is the count $2 \mathrm{n}=54$ for $P$. wendlandii, reported by Subramunian and Munian (1988). On the other hand, there are different counts for the same species, such as $P$. selloum, $2 \mathrm{n}=32,34,36,48, P$. gloriosum, $2 \mathrm{n}=34,33,32,30, P$. cuspidatum, $2 \mathrm{n}=36$, 30, and $P$. scandens, $2 \mathrm{n}=32$ and 30 (cf. Petersen 1989). A similar variation was observed in $P$. imbe, $2 \mathrm{n}=32$, in the present work, and $2 \mathrm{n}=34$ (Pfitzer, 1957; Tsuchiya and Takada, 1962). If these disagreements are not due to erroneous species identifications, it can be concluded that aneuploidy plays a role in intraspecific variation. The basic number for this genus has not yet been established. Grayum (1990) suggests an ascendent and descendent aneuploid series, starting from a basic number $\mathrm{x}=7$ in the evolution of Araceae, which gives rise to primary basic numbers, such as $x=6,8,9$ and perhaps 5, 10 and 11. Subsequent chromosome duplications may have resulted in paleodiploids, based 

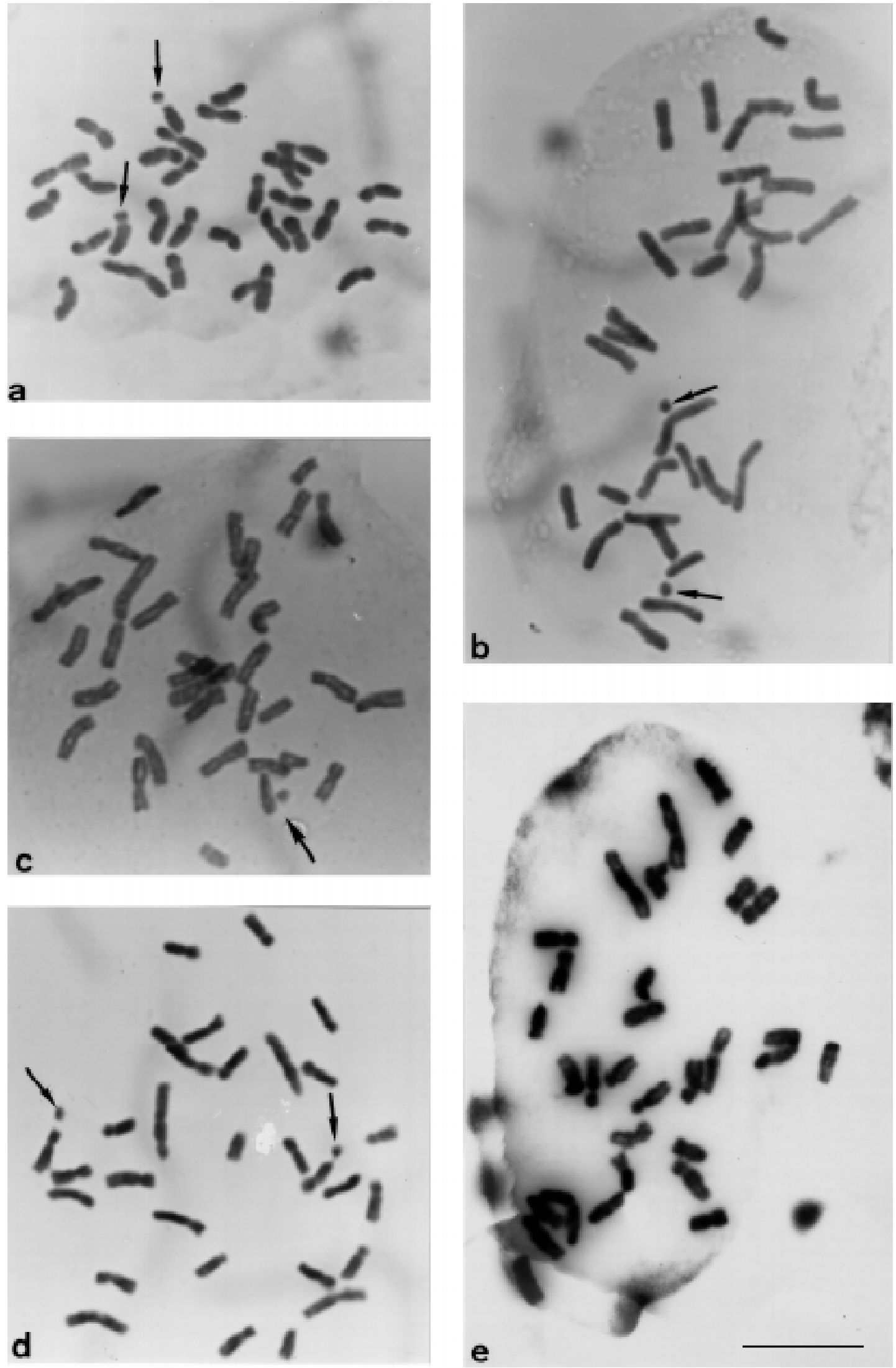

Figure 1 - Mitotic metaphases in Anthurium species. (a) A. affine, $2 \mathrm{n}=30+1 \mathrm{~B}$. (b) A. affine, $2 \mathrm{n}=30+2 \mathrm{~B}$. (c) A. affine, $2 \mathrm{n}=30+4 \mathrm{~B}$. (d) A. pentaphyllum var. pentaphyllum $2 \mathrm{n}=30$. (e) A. longipes, $2 \mathrm{n}=30$. Satellites are indicated by arrows. The bar represents $10 \mu \mathrm{m}$. 

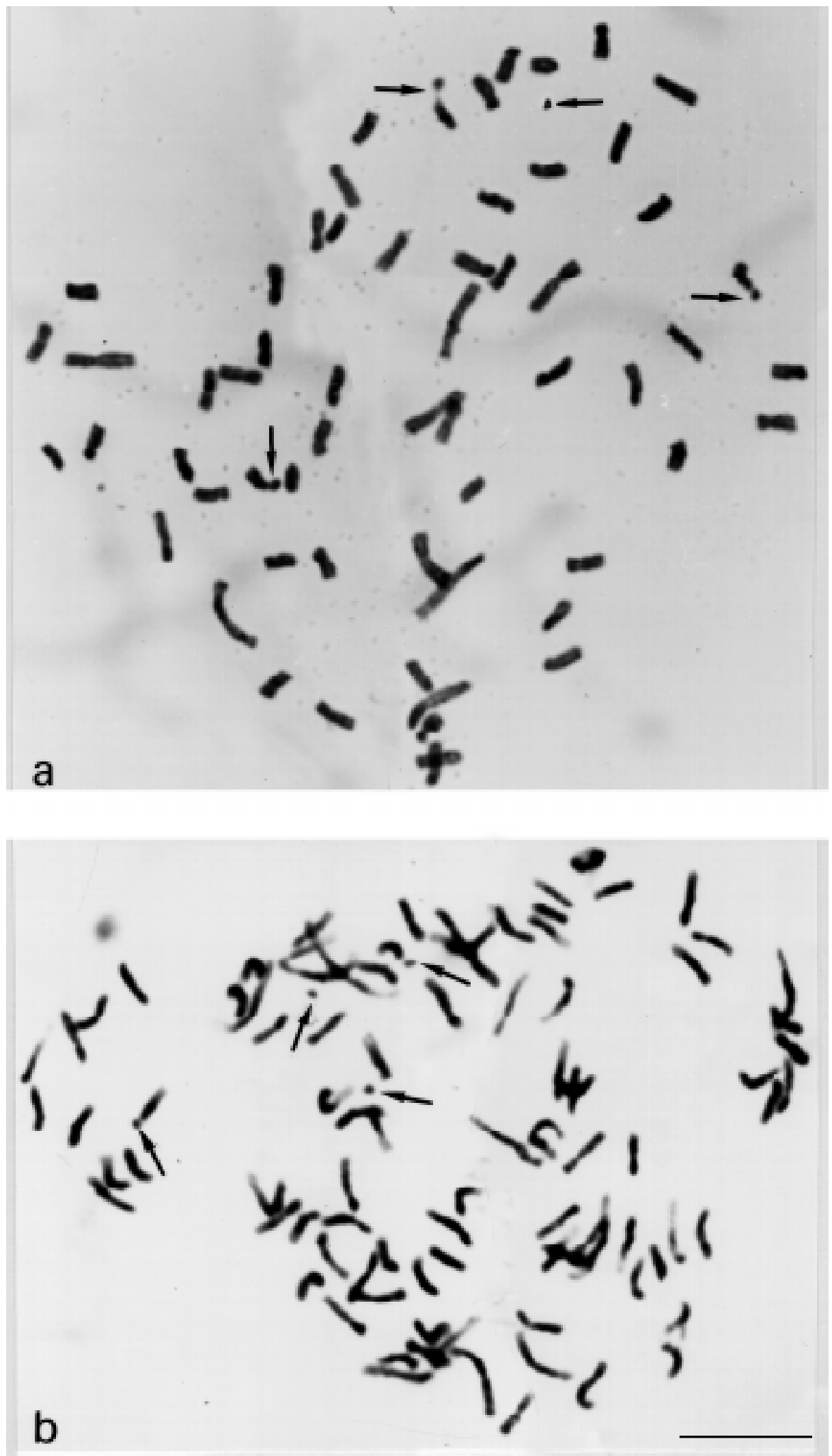

Figure 2 - Mitotic metaphases in polyploid Anthurium species. (a) A. pentaphyllum var. pentaphyllum, $2 \mathrm{n}=60$. (b) A. bellum, $2 \mathrm{n}=$ 90. Satellites are indicated by arrows. The bar represents $10 \mu \mathrm{m}$. 

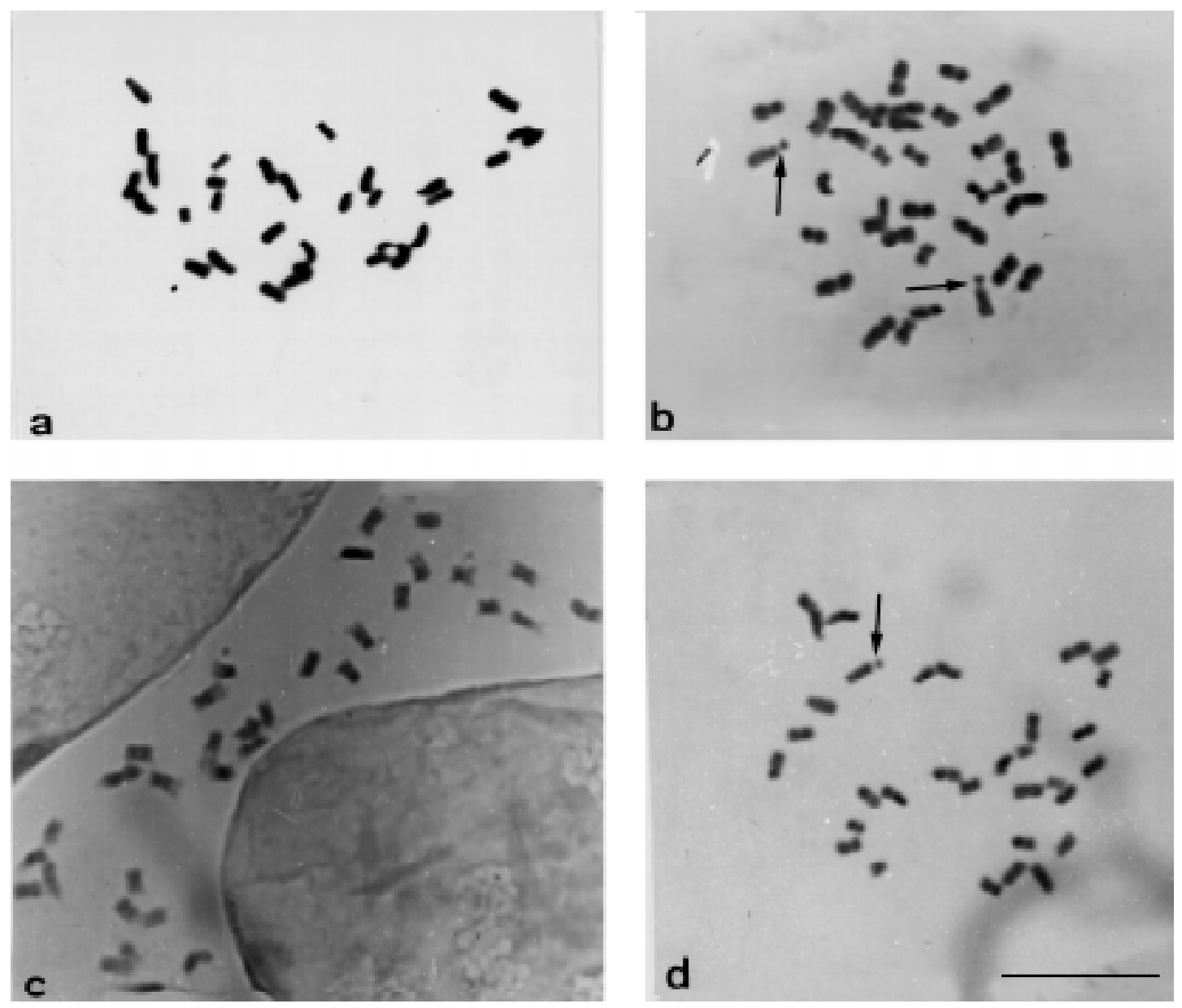

Figure 3 - Mitotic metaphases in Philodendron species. (a) P. pedatum, $2 \mathrm{n}=32$. (b) P. pachyphyllum $2 \mathrm{n}=34$. (c) P. blanchetianum $2 \mathrm{n}=34$. (d) $P$. imbe $2 \mathrm{n}=32$. Satellites are indicated by arrows. The bar represents $10 \mu \mathrm{m}$.

on these numbers. Afterwards, autopolyploidy and amphiploidy must have played an important role in the evolution of the genera. The diploid number $2 \mathrm{n}=32$ in $P$. imbe and $P$. pedatum must be based on the primary basic number $\mathrm{x}=8$, while the diploid number $2 \mathrm{n}=34$, observed in $P$. blanchetianum and P. pachyphyllum, may have an amphidiploid origin, involving species with $\mathrm{x}=8$ and $\mathrm{x}=9$, and subsequent chromosome duplication. In a similar way, in Anthurium it is possible that amphiploidy, involving primary basic numbers $x=7$ and $x=8$, gave rise to the basic secondary number $x=15$, present in most previous counts. The counts $2 n=60$ and $2 n=90$, in the present work, and $2 \mathrm{n}=124(120+4$ B-chromosomes $)$ in A. lucidum and Anthurium sp. (Marchant, 1973) are multiples of this basic number. The count variations $2 \mathrm{n}=31,32,34,35$ and 63 (cf. Petersen, 1989) can be explained by additional counts of B-chromosomes. Nevertheless, the $2 \mathrm{n}=56$ counts in A. bellum, not confirmed in the present work, $2 \mathrm{n}$ $=28$ in A. patulum (Sharma and Bhattacharya, 1966), $2 \mathrm{n}$ $=48$ in A. jenmanii (Sheffer and Croat, 1983), $2 \mathrm{n}=20$, 40, 60 in A. gracile (Sheffer and Croat, 1983; Sheffer and
Kamemoto, 1976, as A. scolopendrinum) and $2 \mathrm{n}=44$ in A. scherzerianum (Subramunian and Munian, 1988) suggest the existence of other evolutionary lines in Anthurium. Additional cytological analysis in a larger number of species is important for establishing the basic number, as well as understanding trends in chromosome evolution within the genus. In the State of Bahia, almost all Philodendron and Anthurium species are endemic and belong to complexes whose developmental center lies in the Atlantic forest region. Distinct speciation patterns are found within eastern Brazil, though an affinity with several species from other regions in South America is also apparent (Mayo, 1984). For this reason, South American species represent an important study source, both for their evolutionary history and present diversity, and because there is no chromosome data for a large number of species.

\section{ACKNOWLEDGMENTS}

The authors are very grateful to Dr. Simon Mayo, from Royal Botanic Gardens, Kew, for the taxonomic help. 


\section{RESUMO}

O número de cromossomos de quatro espécies de $A n$ thurium e quatro espécies de Philodendron coletadas no Estado da Bahia, Brasil, foi determinado. As contagens $2 \mathrm{n}=30$ para $A$. longipes e $A$. affine, $2 \mathrm{n}=32$ para $P$. pedatum e $2 \mathrm{n}=34$ para $P$. blanchetianum e P. pachyphyllum representam o primeiro registro para estas espécies. Os números diplóides $2 \mathrm{n}=32$ encontrado para $P$. imbe e $2 \mathrm{n}=90$ para $A$. bellum diferem de registros anteriores, enquanto $2 \mathrm{n}=30$ e 60 para $A$. pentaphyllum var. pentaphyllum confirmam determinações anteriores. A. affine tem um a quatro cromossomos $\mathrm{B}$. Nós sugerimos o número básico secundário x $=15$ para Anthurium e x =16, 17 e 18 para Philodendron, produzidos por hibridações e duplicações envolvendo os números básicos primários $\mathrm{x}=7,8$ e 9 .

\section{REFERENCES}

Brat, S.V. (1965). Genetics systems in Allium. I. Chromosome variation. Chromosoma 16: 486-499.

Croat, T.B. and Sheffer, R.D. (1983). The sectional groupings of Anthurium (Araceae). Aroideana 6: 85-123.

D'Ovidio, R. and Marchi, P. (1990). DNA content, karyotype structure analysis and karyotype symmetry in Ranunculus L (Ranunculaceae). Italian species belonging to sections Flammula (Webb) Benson and Micranthus (Ovcz) Nyarady. Caryologia 43: 99-115.
Grayum, M.H. (1990). Evolution and phylogeny of the Araceae. Ann. Missouri Bot. Gard. 77: 628-697.

Marchant, C.J. (1973). Chromosome variation in Araceae: V. Acoreae to Lasieae. Kew Bull. 28: 199-210.

Mayo, S.J. (1984). Aspectos da fitogeografia das aráceas bahianas. Anais XXIV Congr. Nac. Bot., Porto Alegre, Brasil 2: 215-227.

Mayo, S.J. (1990). History and infrageneric nomenclature of Philodendron (Araceae). Kew Bull. 45: 37-71.

Mookerjea, A. (1955). Cytology of different species of Aroids with a view to trace the basis of their evolution. Caryologia VIII: 221-291.

Petersen, G. (1989). Cytology and systematics of Araceae. Nord. J. Bot. 9: 119-158.

Pfitzer, P. (1957). Cromosomenzahlen von Araceen. Chromosoma Bd. 8: 436-446.

Samuel, R., Smith, J.B. and Bennet, M.D. (1986). Nuclear DNA variation in Piper (Piperaceae). Can. J. Genet. Cytol. 28: 1041-1043.

Sharma, A.K. and Bhattacharya, G.N. (1966). A cytotaxonomic study on some taxa of Araceae. Genét. Ibér. 18: 1-26.

Sharma, A.K. and Sharma, A. (1980). Chromosome Techniques: Theory and Practice. 3rd edn. Butterworths, Woburn, MA, pp. 95-105.

Sheffer, R.D. and Croat, T.B. (1983). Chromosome numbers in the genus Anthurium (Araceae) II. Am. J. Bot. 70: 858-871.

Sheffer, R.D. and Kamemoto, H. (1976). Chromosome numbers in the genus Anthurium. Am. J. Bot. 63: 74-81.

Subramunian, D. and Munian, M. (1988). Cytotaxonomical studies in South Indian Araceae. Cytologia 53: 59-66.

Tsuchiya, T. and Takada, M. (1962). Chromosome studies in five species of Araceae. Chrom. Inf. Serv. 3: 36-38.

(Received March 16, 1998) 